\section{Cardiovascular stability with rapid intravenous infusion of ondansetron}

Julius S. Heyman PhD, ${ }^{*}$ Marie L. Young MD, ${ }^{*}$ Roger J. Bagshaw MD, ${ }^{*}$ Warren J. Levy MD,* Ralph T. Geer MD,* Stanley J. Aukburg MD,* Alan F. Joslyn PhD, $\dagger$ Thomas J. Conahan $\mathrm{MD}^{*}$
The acute cardiovascular effects of rapid iv administration of the antiemetic ondansetron, a selective serotonin $\left(5-H T_{3}\right)$ receptor antagonist were determined in a randomized, blinded, placebo-controlled study. Measurements of heart rate, blood pressure, oxygen saturation and respiratory rate were made preoperatively over a five-minute period which followed a twominute infusion of the medication. Intraoperative and postoperative data were not collected. None of the variables recorded changed significantly during the infusion or in the observation period which followed. Within the limitations of this study, we detected no cardiovascular change in the five minutes between the end of the drug infusion and the induction of anaesthesia.

Les effets cardiovasculaires immédiats d'un injection rapide intraveineuse de lantiémétique antagoniste sélectif de la sérotonine (5- $\mathrm{HT}_{3}$, l'ondansetron, sont évalués dans cette étude randomisée à double inconnue avec placébo. Des mesures de la fréquence cardiaque, de la pression artérielle, de la saturation en oxygène et de la fréquence respiratoire sont réalisées à la période préopératoire pendant les cinq minutes qui ont suivi la perfusion d'une durée de deux minutes du médicament. On ne pas recueille pas les données per-et postopératoires. Aucun des paramètres enregistrés n'est modifié pendant la perfusion ou pendant la période d'observation subséquente. Au cours de cette étude, n'avons pas détecté de perturbations cardiovasculaires pendant les cinq minutes écoulées entre la fin de la perfusion et le début de l'anesthésie.

\section{Key words}

COMPLICATIONS: haemodynamic, respiratory; SEROTONIN: antagonists, ondansetron; VOMITING: antiemetics.

From the Department of Anaesthesia, University of Pennsylvania* and Glaxo, Inc. $\dagger$

This work was done in the Day Surgery Unit, Hospital of the University of Pennsylvania, Philadelphia, PA.

Supported by a grant from Glaxo Inc.

Presented at the 1992 Annual Meeting of the International Anaesthesia Research Society.

Address correspondence to: Dr. Thomas J. Conahan, Department of Anaesthesia, Hospital of the University of Pennsylvania, 3400 Spruce Street, Philadelphia, PA 19104. Accepted for publication 2nd February, 1993.
Ondansetron is a highly selective and potent serotonin (5-HT) receptor antagonist. ' It has been shown to be very effective in controlling chemotherapy ${ }^{2}$ and radiotherapy ${ }^{3}$-induced emesis. Oral ondansetron given before surgery reduces the incidence of postoperative nausea and vomiting. ${ }^{4}$ Intravenous formulations have been used to treat postanaesthetic nausea and vomiting. ${ }^{5}$ Preoperative administration of $\dot{i}$ ondansetron reduced the incidence of postoperative vomiting in a small group of patients, but did not affect the incidence of nausea. ${ }^{6}$ The patients reported in our study are a subset of a multi-centre investigation which found that both nausea and vomiting were reduced by preoperative ondansetron. ${ }^{\text {? }}$

Serotonin receptors have been implicated in changes in heart rate and blood pressure, ${ }^{8}$ but delineation of specific receptor activity has been complicated. These receptors are found in both the central and peripheral nervous systems as well as in smooth muscle and platelets. Four main types of 5-HT receptor have been identified, $5-\mathrm{HT}_{1}$, $5-\mathrm{HT}_{2}, 5-\mathrm{HT}_{3}$, and $5-\mathrm{HT}_{4},{ }^{9,10}$ with $5-\mathrm{HT}_{1}$, and $5-\mathrm{HT}_{3}$ being divided further into subtypes. "All four types of 5-HT receptor have been implicated in cardiovascular regulation in animals and humans. ${ }^{2}$ This study was undertaken to determine the effects of rapid $i v$ administration of the $5-\mathrm{HT}_{3}$ antagonist ondansetron on heart rate, blood pressure, respiratory rate and oxygen saturation in patients about to undergo general anaesthesia.

\section{Methods}

Institutional Review Board approval was obtained for the study. Seventy-one female patients, ASA I or II, ranging in age from 20 to $62 \mathrm{yr}$ and scheduled for surgery requiring general endotracheal anaesthesia granted informed consent. Patients were randomly assigned to receive $20 \mathrm{ml}$ of a solution which contained $0,1,4$ or $8 \mathrm{mg}$ of ondansetron (Glaxo, Research Triangle Park, NC). After preanaesthetic evaluation, an $i v$ infusion of $5 \%$ dextrose in $0.45 \%$ saline was begun and the patient was taken to the operating room. Supine measurements of heart rate, systolic and diastolic blood pressure (Dinamap, Critikon), respiratory rate and oxygen saturation (pulse oximeter, Nellcor) were recorded. No preanaesthetic medication was administered. The study drug solution was then infused over two minutes. Heart rate and 
TABLE I Characteristics of the study groups. (Surgery time is from incision to dressing placement. Recovery time is from admission to recovery room until discharge home.)

\begin{tabular}{lllllll}
\hline $\begin{array}{l}\text { Ondansetron } \\
\text { dose }(\mathrm{mg})\end{array}$ & $n$ & $\begin{array}{l}\text { Age } \\
(\mathrm{yr})\end{array}$ & $\begin{array}{l}\text { Weight } \\
(\mathrm{kg})\end{array}$ & $\begin{array}{l}\text { Height } \\
(\mathrm{cm})\end{array}$ & $\begin{array}{l}\text { Surgery } \\
\text { time (min) }\end{array}$ & $\begin{array}{l}\text { Recovery } \\
\text { time (min) }\end{array}$ \\
\hline 0 & 18 & $36 \pm 9$ & $63 \pm 9$ & $166 \pm 7$ & $62 \pm 28$ & $126 \pm 12$ \\
1 & 18 & $34 \pm 6$ & $64 \pm 9$ & $163 \pm 6$ & $48 \pm 26$ & $138 \pm 23$ \\
4 & 16 & $36 \pm 10$ & $67 \pm 16$ & $164 \pm 7$ & $53 \pm 22$ & $143 \pm 43$ \\
8 & 19 & $33 \pm 6$ & $67 \pm 12$ & $165 \pm 9$ & $56 \pm 25$ & $143 \pm 36$ \\
\hline
\end{tabular}

Mean values $\pm \mathrm{SD}$.

TABLE II Effects of intravenous ondansetron infusion on heart rate*

\begin{tabular}{|c|c|c|c|c|c|c|c|}
\hline \multirow[b]{2}{*}{ Ondansetron dose $(\mathrm{mg})$} & \multicolumn{2}{|l|}{ Infusion } & \multicolumn{5}{|c|}{ Time after infusion } \\
\hline & Start & End & $1 \mathrm{~min}$ & $2 \min$ & $3 \mathrm{~min}$ & $4 \min$ & $5 \min$ \\
\hline 0 & $77 \pm 13$ & $77 \pm 12$ & $78 \pm 13$ & $78 \pm 12$ & $76 \pm 13$ & $77 \pm 15$ & $78 \pm 15$ \\
\hline 1 & $80 \pm 12$ & $77 \pm 11$ & $80 \pm 10$ & $79 \pm 12$ & $77 \pm 12$ & $79 \pm 13$ & $80 \pm 12$ \\
\hline 4 & $75 \pm 10$ & $74 \pm 10$ & $74 \pm 10$ & $75 \pm 9$ & $75 \pm 10$ & $76 \pm 9$ & $76 \pm 9$ \\
\hline 8 & $74 \pm 12$ & $75 \pm 13$ & $74 \pm 13$ & $73 \pm 11$ & $75 \pm 12$ & $76 \pm 14$ & $76 \pm 14$ \\
\hline
\end{tabular}

Mean values $\pm \mathrm{SD}$.

*Beats per minute.

oxygen saturation, blood pressure and respiratory rate were recorded at the beginning and end of drug infusion and once per minute thereafter for five minutes. Anaesthesia was induced at the conclusion of the study period and only the measurements usually associated with a clinical anaesthesia record (vital signs, etc. every five minute) were recorded. Neither the observer nor the anaesthetist caring for the patient was aware of the composition of the study solution.

The data are presented as the mean value and standard deviation of the respective variables at each measurement point. Differences among groups were sought using multiple analysis of variance. Systolic and diastolic blood pressure were analyzed separately.

\section{Results}

The groups were comparable in age, height and weight as well as in duration of surgical procedure, and recovery room stay (Table I). About $80 \%$ of the patients in each group had gynaecological laparoscopic procedures. The remaining patients were distributed among plastic, orthopaedic, general and oral surgery. The case mix in each group was similar, although prospective assignment by type of surgical procedure was not done. There were no clinically or statistically significant changes in heart rate during the five-minute period following administration of placebo or ondansetron (Table II).

We could detect no clinically significant change in either the systolic (Table III) or diastolic (Table IV) blood pressure in patients who received any amount of ondansetron. Respiratory rate (Table V) and oxygen saturation levels (Table VI) were similarly unaffected.

\section{Discussion}

This study was designed to detect clinically important changes in the variables normally monitored in the preanaesthesia period. It was performed in a clinical setting using patient volunteers.

The period of observation in these unpremedicated preoperative patients was held to seven minutes (two minutes infusion, five minutes post-infusion sampling). The time to peak concentration of ondansetron administered intravenously over five minutes has been reported as seven minutes. ${ }^{13}$ We felt that, given the rapid (two minutes) administration of the drug in this study, a five-minute observation period would be adequate to demonstrate clinically important cardiovascular actions of the drug. Observations were not carried into the post-anaesthesia induction period because of the variability of cardiovascular responses during anaesthesia. The physicians caring for these patients reported no unusual cardiovascular responses nor ECG changes in the patients who had received the study drug.

Serotonin, acting at $5-\mathrm{HT}_{3}$ receptors, can either speed or slow the heart rate in a number of species. In many animals, 5-HT induces reflex bradycardia and hypotension known as the Bezold-Jarisch reflex by activating epicardial or ventricular receptors normally triggered by at- 
TABLE III Effects of intravenous ondansetron infusion on systolic blood pressure*

\begin{tabular}{|c|c|c|c|c|c|c|c|}
\hline \multirow[b]{2}{*}{ Ondanseiron dose (mg) } & \multicolumn{2}{|l|}{ Infusion } & \multicolumn{5}{|c|}{ Time after infusion } \\
\hline & Start & End & $I \min$ & $2 \min$ & $3 \mathrm{~min}$ & $4 \min$ & $5 \mathrm{~min}$ \\
\hline 0 & $128 \pm 21$ & $128 \pm 21$ & $123 \pm 19$ & $126 \pm 19$ & $123 \pm 19$ & $123 \pm 19$ & $125 \pm 19$ \\
\hline 1 & $129 \pm 12$ & $125 \pm 17$ & $124 \pm 17$ & $125 \pm 15$ & $123 \pm 13$ & $123 \pm 16$ & $121 \pm 14$ \\
\hline 4 & $126 \pm 14$ & $126 \pm 14$ & $123 \pm 13$ & $121 \pm 14$ & $122 \pm 14$ & $121 \pm 14$ & $120 \pm 15$ \\
\hline 8 & $130 \pm 17$ & $129 \pm 17$ & $126 \pm 16$ & $129 \pm 19$ & $127 \pm 17$ & $128 \pm 19$ & $124 \pm 17$ \\
\hline
\end{tabular}

Mean values $\pm \mathrm{SD}$.

*mmHg.

TABLE IV Effects of intravenous ondansetron infusion on diastolic blood presure*

\begin{tabular}{|c|c|c|c|c|c|c|c|}
\hline \multirow[b]{2}{*}{ Ondansetron dose $(\mathrm{mg})$} & \multicolumn{2}{|l|}{ Infusion } & \multicolumn{5}{|c|}{ Time after infusion } \\
\hline & Start & End & $1 \mathrm{~min}$ & $2 \min$ & $3 \min$ & $4 \min$ & $5 \min$ \\
\hline 0 & $79 \pm 11$ & $79 \pm 11$ & $76 \pm 12$ & $76 \pm 10$ & $75 \pm 10$ & $76 \pm 12$ & $74 \pm 11$ \\
\hline 1 & $79 \pm 7$ & $76 \pm 7$ & $78 \pm 10$ & $75 \pm 8$ & $73 \pm 8$ & $74 \pm 10$ & $72 \pm 9$ \\
\hline 4 & $72 \pm 8$ & $72 \pm 8$ & $71 \pm 7$ & $72 \pm 7$ & $70 \pm 5$ & $70 \pm 9$ & $72 \pm 9$ \\
\hline 8 & $79 \pm 11$ & $77 \pm 12$ & $76 \pm 12$ & $76 \pm 11$ & $75 \pm 11$ & $75 \pm 11$ & $75 \pm 11$ \\
\hline
\end{tabular}

Mean values $\pm \mathrm{SD}$

*mmHg.

TABLE V Effects of intravenous ondansetron infusion on respiratory rate*

\begin{tabular}{|c|c|c|c|c|c|c|c|}
\hline \multirow[b]{2}{*}{ Ondansetron dase $(\mathrm{mg})$} & \multicolumn{2}{|l|}{ Infusion } & \multicolumn{5}{|c|}{ Time after infusion } \\
\hline & Start & End & $1 \min$ & $2 \min$ & $3 \min$ & $4 \min$ & $5 \min$ \\
\hline 0 & $18 \pm 2$ & $18 \pm 2$ & $18 \pm 1$ & $18 \pm 1$ & $18 \pm 1$ & $17 \pm 1$ & $17 \pm 1$ \\
\hline 1 & $18 \pm 2$ & $18 \pm 2$ & $17 \pm 2$ & $17 \pm 2$ & $17 \pm 2$ & $17 \pm 2$ & $17 \pm 1$ \\
\hline 4 & $18 \pm 2$ & $18 \pm 2$ & $17 \pm 2$ & $18 \pm 2$ & $18 \pm 2$ & $18 \pm 2$ & $18 \pm 2$ \\
\hline 8 & $17 \pm 1$ & $18 \pm 2$ & $17 \pm 1$ & $17 \pm 2$ & $18 \pm 2$ & $17 \pm 2$ & $17 \pm 2$ \\
\hline
\end{tabular}

Mean values $\pm \mathrm{SD}$.

* Respirations per minute.

TABLE VI Effects of intravenous ondansetron infusion on oxygen saturation*

\begin{tabular}{|c|c|c|c|c|c|c|c|}
\hline \multirow[b]{2}{*}{ Ondansetron dose $(\mathrm{mg})$} & \multicolumn{2}{|c|}{ Infusion } & \multicolumn{5}{|c|}{ Time after infusion } \\
\hline & Start & End & $I \min$ & $2 \min$ & 3 min & $4 \min$ & $5 \min$ \\
\hline 0 & 99 & 99 & 99 & 99 & 99 & 98 & 99 \\
\hline 1 & 100 & 99 & 100 & 100 & 100 & 100 & 100 \\
\hline 4 & 99 & 100 & 100 & 100 & 100 & 99 & 99 \\
\hline 8 & 100 & 100 & 99 & 100 & 99 & 99 & 98 \\
\hline
\end{tabular}

Mean values.

*Percent saturation.

rial or ventricular pressure. ${ }^{12,14}$ Serotonin is believed to mediate this reflex by activating $5-\mathrm{HT}_{3}$ receptors, since the effect is blocked selectively by a number of $5-\mathrm{HT}_{3}$ antagonists. ${ }^{15-17}$ Serotonin has also been shown to induce tachycardia in the rat ${ }^{18}$ and $\operatorname{dog}^{19}$ either by release of endogenous catecholamines ${ }^{19}$ or by direct activation of $5-\mathrm{HT}_{1},{ }^{18} 5-\mathrm{HT}_{2}{ }^{20}$ and $5-\mathrm{HT}_{3}{ }^{14}$ receptors. Evidence supporting the direct role of $5-\mathrm{HT}_{3}$ receptors in 5-HTinduced tachycardia was provided recently by Wilson $e t$ $a l{ }^{21}$ who created tachycardia in the dog by administering 
a $5-\mathrm{HT}_{3}$ selective agonist $\left(2 \mathrm{CH}_{3}-5-\mathrm{HT}\right)$, then demonstrated dose-dependent reversal of the tachycardia by 5$\mathrm{HT}_{3}$ selective antagonists ondansetron, zacopride and ICS 205-930. Notwithstanding these observations in animals, we found that the rapid $i v$ administration of ondansetron produced no clinically important chronotropic effects in healthy humans.

Also in our study of awake women, we were unable to demonstrate an effect of ondansetron on blood pressure. This lack of effect is intriguing since 5-HT and serotonergic drugs are known to affect cardiovascular reflexes and blood pressure by action at 5- $\mathrm{HT}_{3}$ receptors in the carotid bodies and in vascular beds. Intra-arterial infusion of 5-HT in the human forearm causes vasodilatation which is abolished by ICS 205-930, suggesting the involvement of 5- $\mathrm{HT}_{3}$ receptors. ${ }^{22}$

There is reasonable evidence for the role of the $5-\mathrm{HT}_{3}$ receptor in cardiovascular regulation. In the present study, however, cardiovascular stability was maintained after rapid $\dot{v}$ infusion of the $5-\mathrm{HT}_{3}$ antagonist ondansetron. This could be because ondansetron blocks a 5- $\mathrm{HT}_{3}$ receptor subtype which does not affect heart rate or blood pressure. In rat studies, reflex hypotension was blocked by the antagonists granisetron and ICS 205-930, but not by ondansetron. ${ }^{23}$ However, a more probable explanation of the cardiovascular stability we found lies in the level of serotonergic tone in these systems. That is to say, ondansetron may have had no effect on heart rate or blood pressure because there was little or no basal serotonergic input to the $5-\mathrm{HT}_{3}$ receptors mediating these parameters.

A lack of basal serotonergic tone at cardiovascular 5$\mathrm{HT}_{3}$ receptors is supported by a number of findings. Blauw et al. ${ }^{22}$ reported that intra-arterial infusion of the 5- $\mathrm{HT}_{3}$ antagonist ICS 205-930 alone has no effect on forearm blood flow in humans. They pointed out that it is doubtful whether plasma levels of 5-HT could have any effect on vascular tone under normal conditions since the only physiological important source of 5-HT in the vasculature is the platelets. ${ }^{24}$ Thus, it seems that ondansetron's lack of effect on heart rate and blood pressure may be due to the inactivity of $5-\mathrm{HT}_{3}$ receptors under the conditions imposed in the present study.

Ondansetron is very effective in preventing the nausea and vomiting associated with chemotherapy ${ }^{2}$ and radiotherapy ${ }^{3}$ and appears effective against postanaesthetic emesis, ${ }^{4,5,7}$ Ondansetron has little or no affinity for dopamine receptors, ${ }^{1}$ thus undesirable side effects, such as the sedation and extrapyramidal symptoms associated with the traditional antiemetics prochlorperazine and metoclopramide, are minimal. The present study demonstrates that cardiovascular stability is maintained after administration of ondansetron. Antagonism at $5-\mathrm{HT}_{3}$ receptors may endow ondansetron with other actions po- tentially beneficial to the anaesthetized patient, including blockade of pulmonary $\mathrm{J}$ receptors which produce bradycardia, hypotension and rapid shallow breathing when stimulated, ${ }^{8}$ and possible prevention of ventricular arrhythmias. 25

In conclusion, the present study demonstrates that heart rate, blood pressure, respiratory rate and oxygen saturation were not acutely affected by rapid $i v$ administration of ondansetron in healthy patients. Thus it appears that a drug which holds promise for both prevention and treatment of perioperative nausea and vomiting may be administered without fear of cardiovascular or respiratory depression. The ultimate statement that ondansetron is safe for prophylactic preanaesthetic administration awaits studies with detailed intraoperative data gathering and prolonged postoperative observation.

\section{References}

1 Butler A, Hill JM, Ireland SJ, Jordan CC, Tyers $M B$ Pharmacological properties of GR38032F, a novel antagonist at 5- $\mathrm{HT}_{3}$ receptors. Br J Pharmacol 1988; 94: 397-412.

2 De Mulder PHM, Seynaeve C, Vermorken JB, et al. Ondansetron compared with high-dose metoclopramide in prophylaxis of acute and delayed cisplatin-induced nausea and vomiting. A multicenter; radomized, double-blind, crossover study. Ann Intern Med 1990; 113: 834-40.

3 Priestman TJ. Clinical studies with ondansetron in the control of radiation-induced emesis. Eur J Cancer 1989; 25 (suppl 1): S29-33.

4 Leeser J, Lip H. Prevention of postoperative nausea and vomiting using ondansetron, a new, selective, $5-\mathrm{HT}_{3}$ receptor antagonist. Anesth Analg 1991; 72: 751-5.

5 Bodner $M$, White PF. Antiemetic efficacy of ondansetron after outpatient laparoscopy. Anesth Analg 1991; 73: 250-4.

6 Alon E, Himmelseher S. Ondansetron in the treatment of postoperative vomiting: a randomized, double-blind comparison with droperidol and metoclopramide. Anesth Analg 1992; 75: 561-5.

7 Khalil S, Kallar S, Zahl K, et al. Ondansetron prevents postoperative nausea and vomiting in outpatient females. Anesthesiology 1992; 77: A18.

$8 \mathrm{McQueen} D S$. Cardiovascular reflexes and 5-hydroxytryptamine. In: Saxena PR, Wallis DJ, Wouters W, Bevan P (Eds.). Cardiovascular Pharmacology of 5-Hydroxytryptamine. Dordrecth: Kluwer Academic Publishers, 1990; 233-45.

9 Bradley PB, Engel G, Feniuk W, et al. Proposals for the classification and nomenclature of functional receptors for 5-hydroxytryptamine. Neuropharmacology 1986; 25 : 563-76.

10 Kaumann AJ, Sanders $L$, Brown AM, Murray KJ, Brown 
MJ. A 5-hydroxytryptamine receptor in human atrium. $\mathrm{Br}$ J Pharmacol 1990; 100: 879-85.

11 Richardson BP, Engel $G$. The pharmacology and function of 5-HT 3 receptors. Trends Neurosci 1986; 99: 424-8.

12 Saxena PR, Villalón CM. 5 Hydroxytryptamine: a chameleon in the heart. Trends Pharmacol Sci 1991; 12: 223-7.

13 Colthup PV, Palmer $J L$. The determination in plasma and pharmacokinetics of ondansetron. Eur J Cancer 1989; 25 Suppl I: S71-4.

14 Fozard JR. MDL 72222: a potent and highly selective antagonist at neuronal 5-hydroxytryptamine receptors. Naunyn Schmiedebergs Arch Pharmacol 1984; 326: 36-44.

15 Richardson BP, Engel G, Donatsch P, Stadler PA. Identification of serotonin M-receptor subtypes and their specific blockade by a new class of drugs. Nature 1985; 316: 126-31.

16 Smith WW, Sancilio LF, Owera-Atepo JB, Naylor RJ, Lambert $L$. Zacopride, a potent $5-\mathrm{HT}_{3}$ antagonist. J Pharm Pharmacol 1988; 40: 30I-2.

17 Saxena PR, Mylecharane EJ, Heiligers J. Analysis of the heart rate effects of 5-hydroxytryptamine in the cat; mediation of tachycardia by 5 - $\mathrm{HT}_{1}$-like receptors. Naunyn Schmiedebergs Arch Pharmacol 1985; 330: 121-9.

18 Docherty $J R$. Investigations of cardiovascular 5hydroxytryptamine receptor subtypes in the rat. Naunyn Schmiedebergs Arch Pharmacol 1988; 337: 1-8.

19 Kimura T, Satoh S. Presynaptic inhibition by serotonin of cardiac sympathetic transmission in dogs. Clin Exp Pharmacol Physiol 1983; 10: 535-42.

20 Saxena PR, Lawang $A$. A comparison of cardiovascular and smooth muscle effects of 5-hydroxytryptamine and 5-carboxamidotryptamine, a selective agonist of 5- $\mathrm{HT}_{1}$ receptors. Arch Int Pharmacodyn Ther 1985; 277: 232-52.

21 Wilson H, Coffman WJ, Cohen ML. 5-Hydroxytryptamine $_{3}$ receptors mediate tachycardia in conscious instrumented dogs. J Pharmacol Exp Ther 1990; 252: 683-8.

22 Blauw GJ, van Brummelen P, van Zwieten PA. Serotonin induced vasodilatation in the human forearm is antagonized by the selective $5-\mathrm{HT}_{3}$ receptor antagonist ICS 205-930. Life Sci 1988; 43: 1441-9.

23 Moss $H E$, Sanger $G J$. the effects of granisetron, ICS 205-930 and ondansetron on the visceral pain reflex induced by duodenal distension. Br J Pharmacol 1990; 100: 497-501.

24 Blauw GJ, van Brummelen P, van Zwieten PA. Vascular pharmacology of 5-hydroxytryptamine in humans. In: Saxena PR, Wallis DJ, Wouters W, Bevan P (Eds.). Cardiovascular Pharmacology of 5-Hydroxytryptamine. Dordrecht: Kluwer Academic Publishers, 1990; 391-9.

25 Berthold H, Scholtysik $G$, Engel $G$. Inhibition of the 5HT-induced cardiogenic hypertensive chemoreflex by the selective 5-HT 3 receptor antagonist ICS 205-930. Naunyn Schmiedebergs Arch Pharmacol 1989; 339: 259-62. 